\title{
Kinetics gelling process of isolated soy protein into a non-dairy beverage
}

\section{Cinética del proceso de gelificación de la proteína de soja aislada en una bebida no láctea}

DOI: $10.46932 / \mathrm{sfjdv2n3-033}$

Received in: May 1st, 2021

Accepted in: Jun 30th, 2021

\section{IA. Brenda Olivera Bernardini}

Food Engeeniring,

Simon Bolivar University Mexico City

Av. Río Mixcoac 48, Insurgentes Mixcoac, Benito Juárez, 03920 Ciudad de México, CDMX

E-mail: brenob89@gmail.com

\section{Prof. Rodrigo González González}

Biochemestry Engeeniring,

Simon Bolivar University Mexico City

Av. Río Mixcoac 48, Insurgentes Mixcoac, Benito Juárez, 03920 Ciudad de México, CDMX

E-mail: rodrgogo@hotmail.com

\begin{abstract}
Soy proteins are used for their emulsifying, foaming, gelling properties, among others. These characteristics can be modified depending on the conditions to which the product is located. These modifications can now be risky for companies that evaluate product shelf life. Non-dairy products, such as soy-based beverages are the model for characterizing protein gelling kinetics by subjecting them to four different temperature and concentration changes, checking the viscosity of the product after a while. This work evaluated a soy-based drink by adding soy protein isolate at concentrations of 3\% 4\%,5\% and $6 \%$ and then taking it to pasteurization, which would help us make a safe drink. Once pasteurized, tests were placed at the temperature of $45^{\circ} \mathrm{C}, 60^{\circ} \mathrm{C}, 65^{\circ} \mathrm{C}$, and $80^{\circ} \mathrm{C}$ respectively for 48 hours to see a change in the properties in the beverages and calculate the gelling curve of each concentration with each temperature. To see the change generated before and after the temperature, viscosity measures were taken, which will help us to have a clearer change from what happens to the isolated soy protein. Curves and kinetic parameters were obtained by making significant differences mainly at a higher temperature and at high concentration, I have even suspended particles forming a gel type in the drink.
\end{abstract}

Key words: Soy protein, temperature, kinetics, concentration, time

\section{RESUMEN}

Las proteínas de soja se utilizan por sus propiedades emulsionantes, espumantes y gelificantes, entre otras. Estas características pueden modificarse en función de las condiciones a las que se encuentre el producto. Estas modificaciones pueden suponer un riesgo para las empresas que evalúan la vida útil del producto. Los productos no lácteos, como las bebidas a base de soja, son el modelo para caracterizar la cinética de gelificación de las proteínas sometiéndolas a cuatro cambios diferentes de temperatura y concentración, comprobando la viscosidad del producto al cabo de un tiempo. En este trabajo se evaluó una bebida a base de soja añadiendo aislado de proteína de soja a concentraciones del 3\%, 4\%, 5\% y 6\%, para luego llevarla a la pasteurización, lo que nos ayudaría a hacer una bebida segura. Una vez pasteurizada, se realizaron pruebas a la temperatura de $45^{\circ} \mathrm{C}, 60^{\circ} \mathrm{C}, 65^{\circ} \mathrm{C}$, y $80^{\circ} \mathrm{C}$ respectivamente durante 48 horas para 
ver un cambio en las propiedades en las bebidas y calcular la curva de gelificación de cada concentración con cada temperatura. Para ver el cambio generado antes y después de la temperatura, se tomaron medidas de viscosidad, lo que nos ayudará a tener un cambio más claro de lo que ocurre con la proteína de soja aislada. Las curvas y parámetros cinéticos se obtuvieron haciendo diferencias significativas principalmente a mayor temperatura y a alta concentración, incluso tengo partículas suspendidas formando un tipo de gel en la bebida.

Palabras clave: Proteína de soja, temperatura, cinética, concentración, tiempo

\section{INTRODUCCIÓN}

Within the design of beverages with soy protein, the objective is to increase the concentration of protein using at least $6.25 \mathrm{~g}$ per portion, in order to be able to declare it as a health claim approved by the "Food and Drug Administration" (FDA). When designing beverages as food supplements, the ideal is that they supply $100 \%$ of the Recommended Daily Intake (RDI), containing the 12 essential amino acids, vitamins, minerals, and 8 to $10 \mathrm{~g}$ of protein providing about $300 \mathrm{Kcal}$ per portion; in this case soy and whey proteins are commonly used in these products for the nutritional and health benefits that both have.. (Bordi, 2006) (Li, 2018) (Venegas Pérez, Restrepo Molina, \& López Vargas, 2009)

During the preparation process of soy milk, soy proteins as mentioned above are prone to denaturation and have a tendency to interact with one or the other while being heated. Many research groups have found the aggregation of soy proteins using pure proteins.

The research of K. Nishinari and collaborators in their work on Soy Proteins: A Review on Composition, Aggregation and Emulsification is an experiment that was proposed as a simulation of the preparation of curd tofu at $60^{\circ} \mathrm{C}$. The usual production of soy milk tofu is heated to much higher temperatures, where the gelling rate is much faster, and where the determination is complicated according to his first experiment in 1991 using coagulant.

Figure 1 Storage modules and loss of shear of soy milk in the presence of GDL at $60^{\circ} \mathrm{C}$. (Nishinari, Fang, Guo, \& Phillips, 2014)

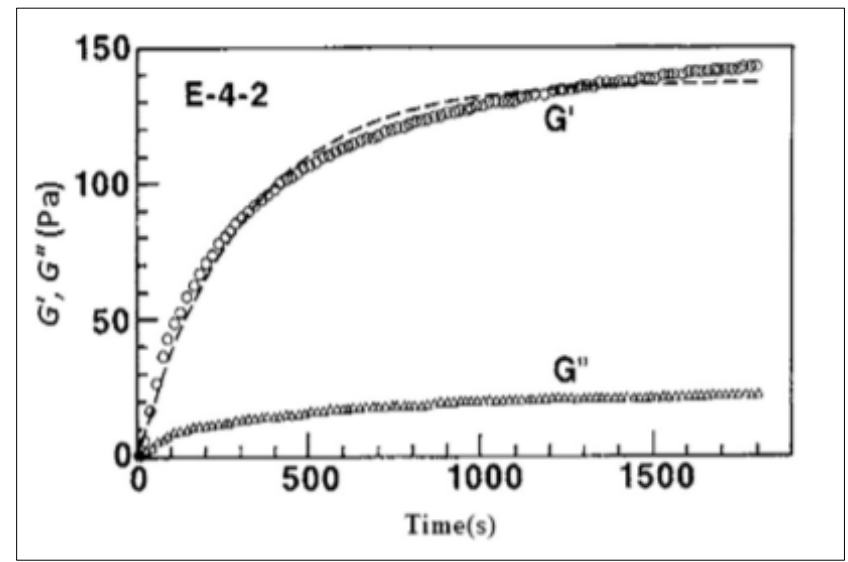


In the same way, the cutting modules were studied in the storage, during the $15 \%$ gelling process $(\mathrm{w} / \mathrm{v})$ the $7 \mathrm{~S}$ globulin solution with $\mathrm{pH} 7.6$, heated to $80^{\circ} \mathrm{C}$ for 30 minutes and then cooled to $20^{\circ} \mathrm{C}$ at a rate of $2^{\circ} \mathrm{C} / \mathrm{min}$ and heated again to $80^{\circ} \mathrm{C}$ at the same rate. Indicating that the hydrophobic interaction between the protein and the medium is important in the formation of a gel

Figure 2 Later, the effect on the cutting module is increased when cooling from $80^{\circ} \mathrm{C}$ to $20^{\circ} \mathrm{C}$ and subsequently decreases when heating from $20^{\circ} \mathrm{C}$ to $80^{\circ} \mathrm{C}$, indicating the contribution of hydrogen bonds in the formation of a network. (Fig. 10)

Figure 2 Gelling process of $15 \%$ globulin $7 \mathrm{~S}$ solution (w/v) at $\mathrm{pH} 7.6$. The solution was heated to $80{ }^{\circ} \mathrm{C}$ for $30 \mathrm{~min}$, cooled to $20{ }^{\circ} \mathrm{C}$ to $2{ }^{\circ} \mathrm{C} / \mathrm{min}$, and then heated to $80{ }^{\circ} \mathrm{C}$ to $2{ }^{\circ} \mathrm{C} / \mathrm{min}$. (Nagano et al., 1994a). (Nishinari, Fang, Guo, \& Phillips, 2014)

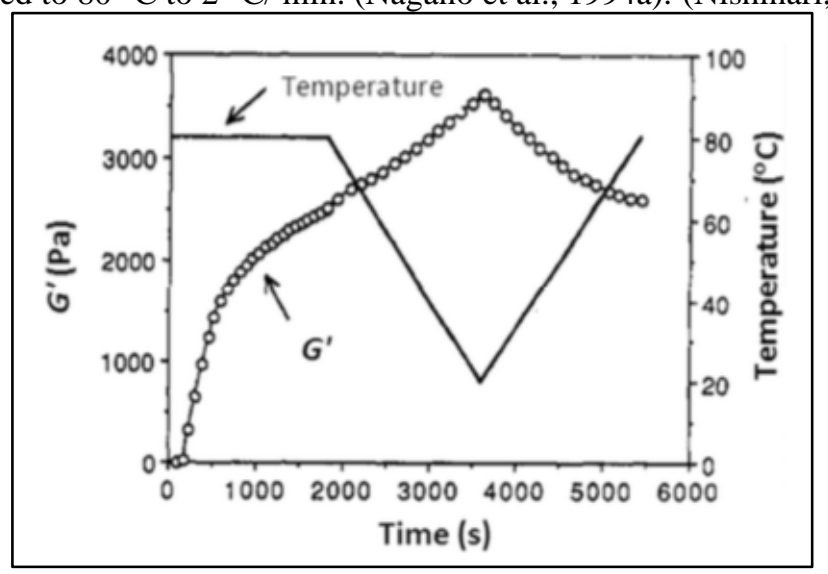

\section{HYPOTHESIS}

Would It be possible to find the limit of protein stability of a non-dairy beverage, using the concentration of isolated protein soy considering the effect of temperature, for the range in which there is no separation of phases nor viscosity modification.

Obtain from a mathematical model of gelling the viscoelasticity modules of a soy-based protein drink from the heat treatment and concentration. Using non-dairy products, such as soy-based beverage, as a model for the characterization of the kinetics of protein gelling, being subjected to four different temperatures and concentrations.

\section{METHODOLOGY}

The methodology was divided into two stages, one experimental and the other analytical. It was based on a base formulation of a drink with soy, consisting of protein isolated from soy, vegetable fat, monkey and diglycerides, emulsifier, sugar and water. A base formulation was used to make the changes in the soy protein composition for the different tests, table 2.

Table 1. First proposal for the formulation of the non-dairy beverage with soy protein isolate. 


\begin{tabular}{|c|c|}
\hline Soy protein isolate & $6 \%$ \\
\hline sucrose & $0.6 \%$ \\
\hline Vegetable fat & $3 \%$ \\
\hline water & $88.25 \%$ \\
\hline Mono- di glycerides & $0.05 \%$ \\
\hline Source: The author.
\end{tabular}

According to the stability of the ingredients used some dispersion was noted., this characteristic helped the mix with the other ingredients such as soy protein and sugar, by changing the density of the beverage with the concentration of the isolated soy protein by $1 \%$ higher in each test giving a combination like Test A 3\%, Test B 4\%, Test C 5\% and Test D 6\%, helping this to verify the changing effect.

Table 2. Formulation used for tests with change in concentration as the main factor.
\begin{tabular}{|c|c|c|c|c|}
\hline & $\begin{array}{c}\text { Test A } \\
\text { \% }\end{array}$ & $\begin{array}{c}\text { Test B } \\
\mathbf{\%}\end{array}$ & $\begin{array}{c}\text { Test C } \\
\mathbf{\%}\end{array}$ & $\begin{array}{c}\text { Test D } \\
\mathbf{\%}\end{array}$ \\
\hline water & 84.9 & 83.9 & 82.9 & 81.9 \\
\hline Soy protein isolate & 3 & 4 & 5 & 6 \\
\hline sugar & 2 & 2 & 2 & 2 \\
\hline Mono-Di glycerides & 0.1 & 0.1 & 0.1 & 0.1 \\
\hline Vegetable fat (Lacteam) & 10 & 10 & 10 & 10 \\
\hline
\end{tabular}

Subsequently, the incubation of the samples was used to simulate in less time the shelf life of the beverages, the temperature was changed from $50^{\circ} \mathrm{C}$ to $80^{\circ} \mathrm{C}$ this to obtain results close to what would happen to the products at these conditions in the market.

\subsection{GELLING}

The gelling was evaluated, by determining the viscosity and protein denaturation of the drink, using as an indirect measure the change of viscosity and determining with the effect of temperature its activation energy.

The "gel time" ( $\left.\mathrm{t}^{*}\right)$ was calculated by extrapolating the increase of $\mathrm{G}^{\prime}$ towards the abstain axis according to the method described by Clark (1991). The results were statistically analyzed using an analysis of variance (ANOVA). To support the gelling characteristic, relative efficiency of solubility equation was used to get the viscosity variable. Therefore, for the verification of this, the measurement of the viscosity of dissolution is carried out, where it defines the resistance to the flow when subjected to the action of a force (or effort) of shear.

Likewise, most macromolecular solutions, including protein solutions, offer a non-Newtonian behavior, especially at high concentrations. In these systems, the viscosity coefficient decreases as the strain rate increases. In which also a protein degradation can be seen due to the water associated with the protein inducing long-distance effects on the flow behavior of the solvent, this was calculated by the 
Arrhenius equation helping to induce the viscosity dependence on the shape and size of protein molecules is given by the expression: 
Equation 1. Viscosity equation of proteins in complex interactions.

\[ \eta_{s p}=\beta C\left(v_{2}+\delta_{1} v_{1}\right) \]
$\eta s p=$ specified viscosity
$B=$ form factor
$C=$ concentration

\section{RESULTS}

To the first tests at $50^{\circ} \mathrm{C}$ for 48 hours, there was a change in the phases of the solution, such as separation of fat and protein with a slight coagulation in the concentrations of $4 \%$ and $5 \%$, while in the concentration of $6 \%$ suffered from decomposition and microbiological growth. But for the next test increasing the temperature to $60^{\circ} \mathrm{C}$ and $65^{\circ} \mathrm{C}$ for 48 hours the separation of the composition is more perceptible but not only for fat and protein but also for the emulsifier and salts, this due to a syneresis between the components that al present.

Thus Hua et al. (2003), evaluated the interactions between soy protein isolate (ISP) and some hydrocolloids, finding that in the ISP kappa carrageenan mixture, the gel strength $\left(\mathrm{G}^{\prime}\right)$ increases with carrageenan concentration, and that the ability to gel the soy protein was significantly increased in the xanthan-protein mixture.

Table 3. Elastic and viscous modules of soy protein gels depending on temperature. Protein content of 3\% $4 \% 5 \%$ and $6 \%$.

\begin{tabular}{|c|c|c|c|c|c|}
\hline & $\begin{array}{c}\text { Concentration/ } \\
\text { Temperature }\end{array}$ & $\mathrm{t} 1\left(50^{\circ} \mathrm{C}\right)$ & $\begin{array}{c}\mathbf{t 2} \\
\left(60^{\circ} \mathrm{C}\right)\end{array}$ & $\mathrm{t3}\left(65^{\circ} \mathrm{C}\right)$ & $\begin{array}{c}\mathrm{t} 4 \\
\left(80^{\circ} \mathrm{C}\right)\end{array}$ \\
\hline 1 & {$[\mathrm{~A}] \mathbf{3 \%}$} & 45 & 45 & 80 & 150 \\
\hline & [B] $4 \%$ & 55 & 75 & 120 & 200 \\
\hline & [C] $5 \%$ & 100 & 150 & 185 & 220 \\
\hline & [D] $6 \%$ & 120 & 155 & 200 & 250 \\
\hline
\end{tabular}

\begin{tabular}{|c|c|c|c|c|c|}
\hline & $\begin{array}{l}\text { Temperature/ } \\
\text { Concentration }\end{array}$ & [A] $3 \%$ & [B] $4 \%$ & {$[\mathrm{C}] \mathbf{5 \%}$} & [D] $6 \%$ \\
\hline 2 & t1 $\left(50^{\circ} \mathrm{C}\right)$ & 25 & 35 & 55 & 85 \\
\hline & t2 $\left(60^{\circ} \mathrm{C}\right)$ & 25 & 45 & 100 & 140 \\
\hline & t3 $\left(65^{\circ} \mathrm{C}\right)$ & 35 & 70 & 120 & 175 \\
\hline & t4 $\left(80^{\circ} \mathrm{C}\right)$ & 79 & 110 & 150 & 190 \\
\hline
\end{tabular}

The viscosity profile is reflected after the tests were subjected to the different temperatures for 48 constant hours, where a viscosity increase profile was expected in relation to the temperature and concentration of the soy protein medium. However, there are two phenomena of phase separation by the degradation of soy protein, based on Graphic 1 it can be inferred that the lower the concentration the separation of phases is more evident in the mixture, but as the concentration increases the effect is lost by 
the saturation of the medium, so it could be deduced that there begins to be a denaturation of proteins, which is what makes them more soluble in the medium decreasing their viscosity and their tendency to gel.

Graphiq 1. Elastic and viscous modules of soy protein gels depending pn temperature. Protein content of $3 \% 4 \% 5 \%$ and
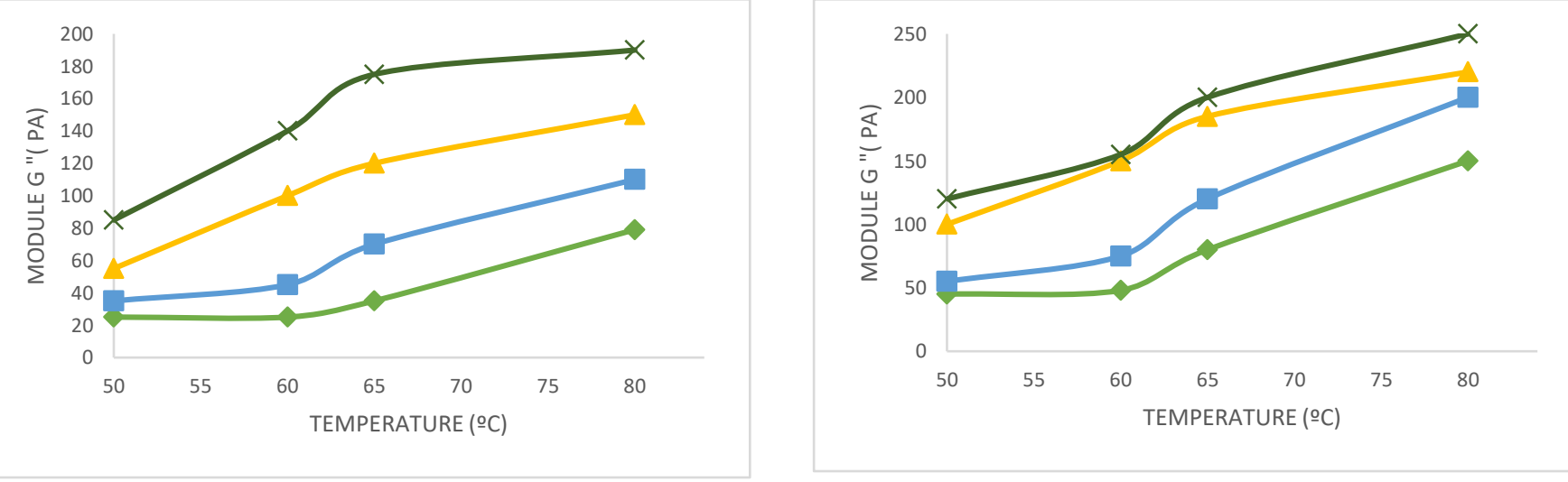

\subsection{STAGE 1: GELLING MECHANISM}

Controlled by the balance between attractive hydrophobic interactions and repulsive electrostatic interactions. These two forces control the balance between protein-protein and protein-solvent interactions in the gelling system. These two forces control the balance between protein-protein and protein-solvent interactions in the gelling system. So, this interaction between the protein and the solvents of the mixture has to do with the ability of the mixture to hydrate, increasing its flexibility and the possibility of forming more hydrophilic bonds, generating a stronger network, increasing in its relative viscosity.

\subsection{STAGE 2: DESNATURALIZATION}

When subjecting the mixture to a heating begins the second step, the denaturation ,where the solution passes to a state PROGEL, which consists of a viscous liquid polymerized where it begins to present the unfolding of the protein exposing to hydrophobic and hydrophilic functional groups, where a protein rich in amino acids comes to suffer ${ }^{1}$ greater hydrophobic aggregation, therefore, the soy protein to contain $100 \%$ PDCAAS and to be subjected to high temperatures suffers from strong hydrophobic interactions, which starts the second step of the phases.

\footnotetext{
${ }^{1}$ PDCAAS, is the Amino acid score corrected for protein digestibility
} 
STAGE 1 AFTER 48 HRS

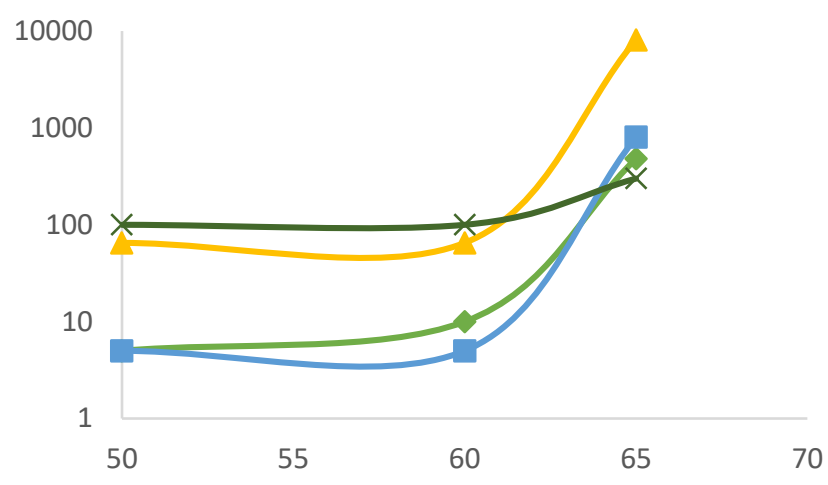

STAGE 2 AFTER 48 HRS

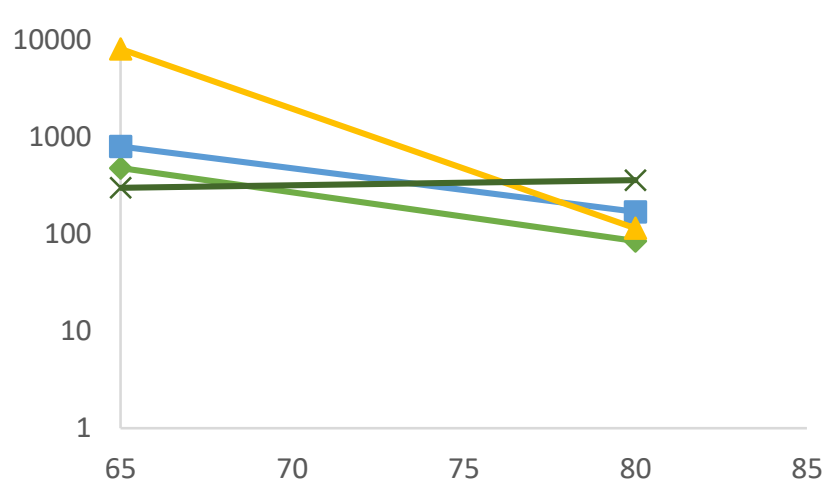

\subsection{STAGE 3: ACTIVATION ENERGY}

According to the solubility of the protein in the solvent, for in which case is water, it can be obtaining the protein fraction in equilibrium with its polar phase and in its non-polar phase, which may vary by the increase of the temperature.

This leads us to establish the amount of activation energy that is being used in the medium to generate this change. For this we are based on Arrhenius equation where by plotting the natural logarithm of viscosity for each of the different concentration vs the inverse of the different temperatures used as shown in table 4 Table each of its trend lines.

Table 4. Results of the logarithm of viscosity $(\mathrm{Pa} * \mathrm{~s})$ and the inverse of temperature $\left({ }^{\circ} \mathrm{K}\right)$ of the samples measured after 48 hours of incubation at constant temperature.

\begin{tabular}{|c|c|c|c|c|}
\hline $\mathbf{1 / T}(\boldsymbol{*} \boldsymbol{k})$ & $\mathbf{L n ~ 3 \%}$ & $\mathbf{L n ~ 4 \%}$ & $\mathbf{L n} \mathbf{5 \%}$ & $\mathbf{L n ~ 6 \%}$ \\
\hline 0.00309 & 1.6094379 & 1.6094379 & 4.1743873 & 4.6051702 \\
\hline 0.00300 & 2.3025851 & 1.6094379 & 4.1743873 & 4.6051702 \\
\hline 0.00296 & 6.1737861 & 6.6846117 & 8.9996193 & 5.7037825 \\
\hline 0.00283 & 4.4426513 & 5.1357984 & 4.7449321 & 5.886104 \\
\hline
\end{tabular}


Graphic 3. Graphics of activation energy viscosities at different concentrations vs temperature change. (1) concentration $3 \%$ and $4 \%$, shows a minimum variation (2) concentration $5 \%$ and $6 \%$, shows no change in the activation energy, which means there is less interaction between the molecules in the medium.

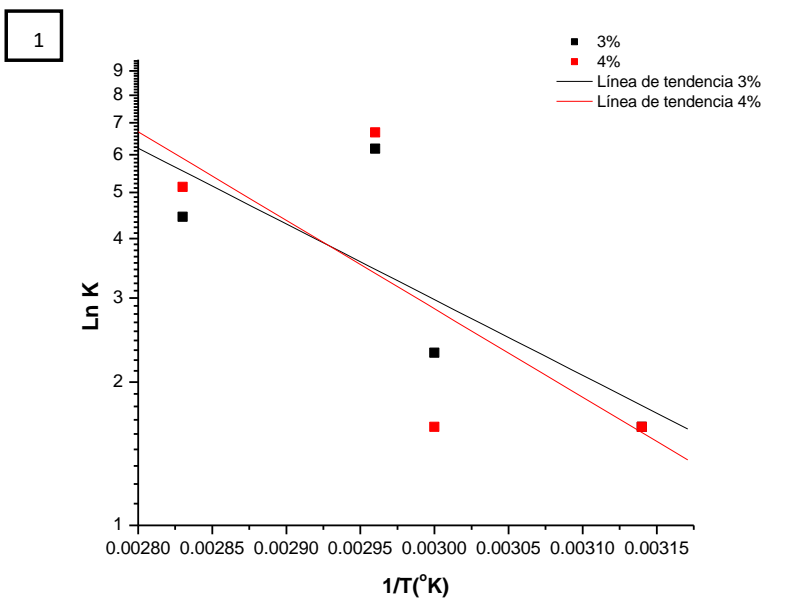

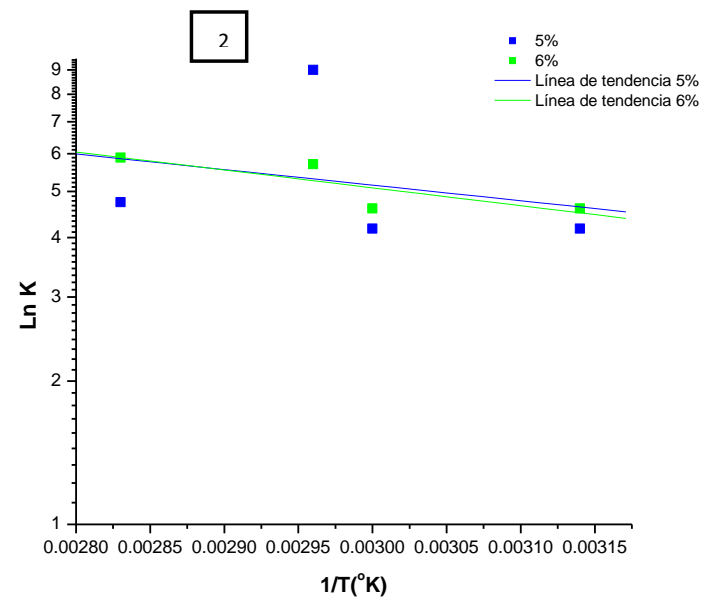

Therefor by putting together the four different concentrations in a graphics, we can see that the point of intersection of the four is between approximately $84{ }^{\circ} \mathrm{C}-78.9^{\circ} \mathrm{C}(0.00280-0.002841 / \mathrm{K})$, which represents the transition zone where the process of denaturation of the soy-isolated protein ends at any of the four concentrations that are managed.

According to the test at different concentrations the activation energy has a lot of influence in the interaction concentration vs temperature, its easier to visualize the change of thermal transition according to the concentration.Graphic The more concentration is in the solution the less activation energy will be and the less visible changes will be, this due to an oversaturation in the system.

Graphic 4. Graph of the behavior of the activation energy in Joules, this according to the concentration of soy protein tested.

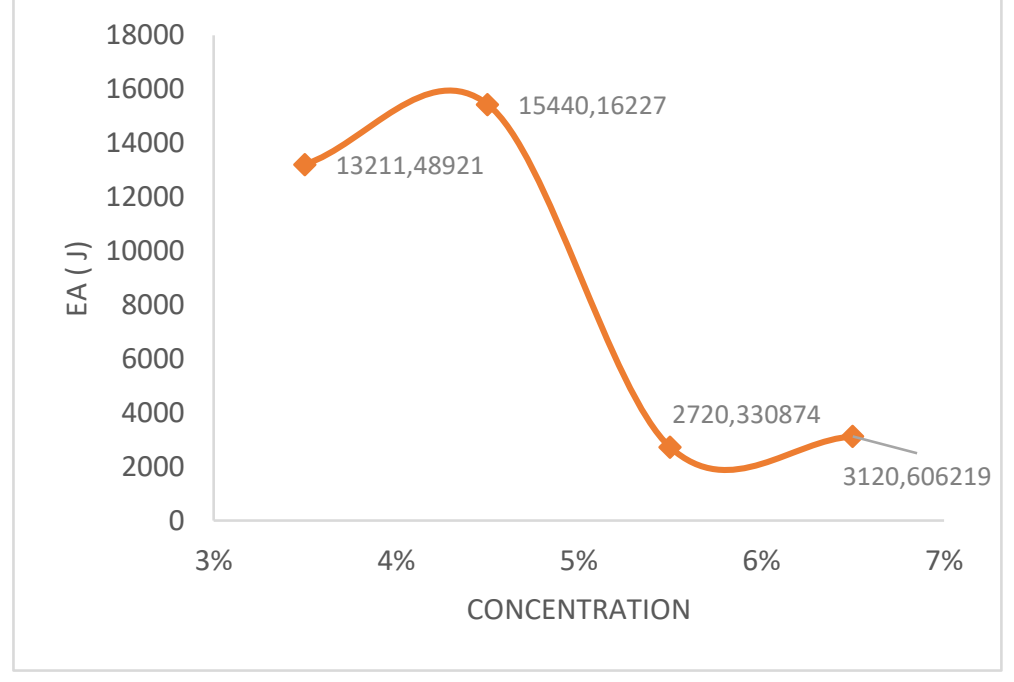




\section{CONCLUSION}

The objective of obtaining a drink with protein substitution formulation was achieved, from the theoretical general formula of a non-dairy beverage added with vegetable protein, achieving this by modifying the concentration of protein isolated from soy, which is our ingredient to be analyzed at different concentrations.

When performing the kinetic study of the changes in concentration along $48 \mathrm{hrs}$ of incubation were observed the change of temperatures founding the separation of phases, possibly due to the denaturation of the protein and later to gelling when reaching the temperature of $60^{\circ} \mathrm{C}$. From this behavior it can be inferred that this is the temperature limit point in the drink for the preservation of its properties as a nondairy drink. This also defines it as a mixture sensitive to a second pasteurization or any thermal process successive to its creation.

From the results found on the solubility of the protein it was proved that in the degradation of the same are separated finding fractions of the same in the aqueous phase and in the organic phase. Therefor in the deformation of the viscosity to the ingredients was identical to that reported in literature so we affirm that the hydrated fraction of the ingredients is diffusion effect before the concentration.

As for the concentration of the vegetable protein added for the creation of the non-dairy drink, we can say that by adding from $15 \mathrm{~g}$ to $30 \mathrm{~g}$ of soy protein isolate to a sample of $500 \mathrm{ml}$, between $13 \mathrm{~g}-26 \mathrm{~g} /$ $500 \mathrm{ml}$ of protein were obtained in the sample. With this information we can say the content of protein in out non dairy mil was higher than the theoretical value of protein contained in a soy drink, which is also 3.2g/100g, published in the Spanish Database of Food Composition (BEDCA)(Ref). Which can be considered an advantage of our drink, taking into account that none of its properties is lost and that it easily adapts to the nutritional limit in accordance 


\section{REFERENCES}

Alvarado, J. d. (2013). Principles of Engineering applied to food (2nd Edition ed.). Ecuador.

Arcand, L. L. (2006). Composition and Functional Properties of Soy Protein Isolates Prepared Using Alternative Defatting and Extraction Procedures. JOURNAL OF FOOD SCIENCE, c-137-c145.

ASA, A. S. (12 of 10, 2019). http://www.asasoya.org/. Retrieved from http://www.asasoya.org/ Badii, M., J., C., M., R., A., W., \& P., V. (2007). Experimental designs and scientific research. Business Innovations, 283-330.

Badui, S. (2006). Food Chemistry (4th Edition ed. ed.). Mexico: Person Education.

Bhatia, V., Singh, P., Wani, S., Chauhan, G., Rao, A. K., Mishra, A., \& Srinivas, K. (2008). Analysis of potential yields and yield gaps of rainfed soybean in India using CROPGRO-Soybean model. agricultural and forest meteorology, 148, 1252-1265.

Bordi, P. G. (2006). A TASTE COMPARISON OF AN ISOLATED SOY PROTEIN CARBOHYDRATE-PROTEIN BEVERAGE AND AN ISOLATED WHEY PROTEIN CARBOHYDRATE-PROTEIN BEVERAGE. Foodservice Research International, 23-33.

Boyd, M. (1998). Organic Chemistry (5th Edition ed. ed.). New York: Pearson Education.

Canales, M., Hernandez, T., Meraz, S., \& Peñalosa, I. (1999). Physicochemistry. Mexico City: MC José Jaime Ávila Valdiveso UNAM.

COFEPRIS. (DOF April 26, 1996). OFFICIAL MEXICAN STANDARD NOM-086-SSA1-1994, GOODS AND SERVICES. FOOD AND BEVERAGESNO ALCOHOLIC WITH MODIFICATIONS IN THEIR COMPOSITION. SPECIFICATIONSNUTRIMENTALES.

Dalgleish, M. A. (2004). Application of transmission diffusing wave spectroscopy to the study of gelation of milk by acidification and rennet Colloids and Surfaces B. Biointerfaces , 83-90.

Fennema, O. (2010). Fennema: Food Chemistry (3rd edition ed.). Zaragoza: Acribia.

Fukushima, D. (1991). STRUCTURES OF PLANT STORAGE PROTEINS AND THEIR FUNCTIONS. Food Reviews International, 7(3), 353-381.

Guadix, A., Guadix, E., Páez-Dueñas, M., \& González-Tello, P. (2000). Technological processes and control methods in protein hydrolysis. 89.

Horneffer, V. T. (2007). Fast characterization of industrial soy protein isolates by direct analysis with matrix-assisted laser desorption onization time-of-flight mass spectrometry. Journal of Agricultural and Food Chemistry, 55 (26), 10505-10508.

J.M. S, R. (2001). Formation, structure and rheological properties of soy protein gels. Netherlands Wageningen University.

J.M.S., R. (2001). Formation, structure and rheological properties of protein gels. Netherlands: Wageningen University. 
K., N. Y. (2014). Soy proteins: A review on composition, aggregation and emulsification. Elsevier, 18. Karina D. Martinez, C.C.-H. (2007). I am protein-polysaccharides interactions at the air-water interface. Food Hydrocolloids, 21 , 804-812.

Katsuyoshi, N. (1997). Rheological and DSC study of sol-gel transition in aqueous dispersions of industrially important polymers and colloids. Colloid and Polymer Science, 275(12), :1093-1107.

Klages, F. (2006). Treatise on Orgenic Chemistry: Systematic Organic Chemistry (Vol. 1). Revert. Retrievedfromhttps://books.google.com.mx/books?id=nhcGf55Gy58C\&pg=PA42\&dq=energ\%C3\%AD a+de+activaci\%C3\%B3n\&hl=en-419\&sa=X\&ved=0ahUKEwj7h6fmz-

7eAhVHJKwKHXClASoQ6AEITzAG\#v=onepage\&q=energ\%C3\%ADa\%20de\%20activaci\%C3\%B3n $\& \mathrm{f}=$ false

Levenspiel, O. (2002). Engineering of chemical reactions. Revert. Retrieved from https://books.google.com.mx/books?id=jF_1vse6AKoC\&pg=PA31\&dq=energ\%C3\%ADa+de+activaci $\%$ C3\%B3n\&hl=en-419\&sa $=$ X\&ved=0ahUKEwiH7sGQ7-

3eAhUI5awKHZy9CtoQ6AEILTAB\#v=onepage \&q=energ\%C3\%ADa\%20de\%20activaci\%C3\%B3n\&f $=$ false

M.D., R. (2006). Chemistry: the basic science. Paraninfo.

Means, G. E., \& Feeney, R. E. (1998). CHEMICAL MODIFICATIONS OF PROTEINS: A REVIEW. Journal of Food Biochemistry, 22, 399-425.

Nishinari, K., Fang, Y., Guo, S., \& Phillips, G. (2014). Soy protein: A review on composition, aggregation and emulsification. Food Hydrocolloids, 39, 301-318. doi:10.1016/j.foodhyd.2014.01.013

Pérez, L., Molina, D., \& Vargas, J. (2009). Characteristics of soy protein drinks.

Renkema, J. (2001). Formation, structure and rheological properties of soy protein gels. Wageningen University. Promoter(in): E. van der Linden; T. van Vliet. - S.1. : S.n. - ISBN 9789058085016 - 121.

Ringgenberg, E., Alexander, M., \& Corredig, M. (2012). Effect of concentration and incubation temperature on the acid induced. Food Hydrocolloids, 463-469. doi:http://dx.doi.org/10.1016/j.foodhyd.2012.05.011

Tolstoguzov, V. (1997). Thermodynamic aspects of dough formation and functionality. Food Hydrocolloids, 11(2), 181-193.

Vanegas Pérez, L. S., Restrepo Molina, D. A., \& López Vargas, J. H. (2009). CHARACTERISTICS OF BEVERAGES WITH SOY PROTEIN. Scielo, 2- 11.

Venegas Pérez, L., Restrepo Molina, D., \& López Vargas, J. (2009). Characteristics of drinks with soy protein. Faculty Nal. Agr. Medellín, 23.

Yamauchi, F. \&. (1984). Rheological behavior of soybean protein-lipid-water gel, from a small distortion to rupture. Agricultural and Biological Chemestry, 2449-2455. 